\title{
Cutting forces optimization in the turning of UD-GFRP composites under different cutting environment with polycrystalline diamond tool
}

\author{
Surinder Kumar ${ }^{1}$; Meenu Gupta ${ }^{2}$; P.S. Satsangi ${ }^{3}$ and H.K. Sardana ${ }^{4}$ \\ ${ }^{1}$ Department of Mechanical Engineering, National Institute of Technology, Kurukshetra 136119, INDIA \\ ${ }^{2}$ Department of Mechanical Engineering, National Institute of Technology, Kurukshetra 136119, INDIA. \\ ${ }^{3}$ Department of Mechanical Engineering, PEC University of Technology, Chandigarh 160012, INDIA. \\ ${ }^{4}$ Department of Computational Instrumentation, CSIO, Chandigarh 160030, INDIA. \\ *Corresponding Author: e-mail: surinder.asd@gmail.com, Phone: +91-9466267889
}

\begin{abstract}
This paper studies the effect of machining parameters on cutting forces (tangential, feed and radial force) for Pultrusion process (UD-GFRP) composite rod in turning operations using (PCD) tool under different cutting conditions (dry, wet and cooled). The experiments were conducted according to $\mathrm{L}_{18}$ orthogonal array. This paper presents an effective approach for the optimization of turning parameters based on the Taugchi's method with regression analysis. Second order predictive model covering tool nose radius, tool rake angle, feed rate, cutting speed, cutting environment (dry, wet and cooled) and depth of cut has been developed at 95\% confidence interval for cutting forces. Minimizing cutting forces is considered as an objective. The results are confirmed by further experiments.
\end{abstract}

Keywords: UD-GFRP composites, ANOVA, cutting forces, polycrystalline diamond tool, Taguchi method, regression modeling

DOI: http://dx.doi.org/10.4314/ijest.v4i2.8

\section{Introduction}

Composite materials are usually of two classifications - plies or lamina - and their usage has dramatically changed the traditional way of working with monolithic materials. Since the demand for low weight ratio, high stiffness, high specific strength and high specific modulus material are made by industries in the aircraft, sporting goods, construction, and automobiles area, the need for more investigations on composites from material performance improvement perspective is necessary. The usage of composite material is a breakthrough in the field of material development technology (Gordon et al., 2002). Composite structure materials have been successfully substituted for traditional materials in several lightweight and high strength applications. As a result, the use of composites has grown considerably, particularly in the aerospace, aircraft, automobile, sporting goods, transportation, power generation and marine industries. Machining of these materials poses particular problems that are seldom seen with metals due to the inhomogeneity, anisotropy and abrasive characteristics of the composites (Abrate and Walton, 1992). Fibre-reinforced plastics (FRP) are extensively utilized in industry as a result of their attractive properties such as high specific modulus, specific strength and damping capacity. They are being commonly used in aerospace and automotive industry, marine applications, sporting goods and biomedical components. Most of the FRP components are manufactured by molding operation almost to the final size of the desired product. However, postproduction machining is sometimes needed to remove excess material at the edge of the component by trimming and to drill holes for dimensional tolerance and assembly requirements, respectively. However, it has been reported that the strong anisotropy and inhomogeneity of FRP introduces many specific problems in machining, such as fibre pullout, delamination, surface damage, burrs and burning.

Conventional machining practices such as turning, milling and drilling are used with composites because of the availability of equipment and experience in conventional machining. Although some of the fibers used in composites are hard (sometimes even harder than the tool material) conventional machining is still used. It can of FRP material removal is accomplished by a series of 
brittle fractures rather than plastic deformation ahead of the tool Caprino and Nele (1996) \& Koplev et al. (1983). Wang and Zhang $(1999,2003)$ characterized the machining damage in unidirectional FRP subjected to cutting and developed a new mechanics model to predict the cutting forces. Mahdi and Zhang (2001) presented a two-dimensional cutting model to predict the cutting forces in relation to fibre orientations and developed an adaptive three-dimensional finite element algorithm. Sun et al., (2004) found that cutting force, cutting temperature and surface roughness increased with increasing cutting speed. Kim and Ehmann (1993) demonstrated that the knowledge of the cutting forces is one of the most fundamental requirements. This knowledge also gives very important information for cutter design, machine tool design and detection of tool wear and breakage. Santhanakrishnan et al. (1989) presented machinability in turning process of GFRP, CFRP and Kevlar fiber reinforced plastics composite using P20 carbide, Tic coated carbide, K20 carbide and HSS tool. Three parameters such as cutting speed, feed rate and depth of cut were selected to minimize surface roughness by using. Scanning electron microscope was use for micrograph. Cutting force, feed force and radial force were measured by using inductive type lath tool dynamometer. It was found that, the K20 carbide tool performed better in machining fiber reinforced plastics composites.

Kevlar fibers reinforced plastics (KFRP) machined surface exhibit poor surface finish due to the fussiness caused by delaminated, dislocated and strain ruptured tough Kevlar fibers (Santhanakrishnan et al., 1989). The effect of main cutting parameters on cutting force and surface roughness in machining alumina reinforced $\mathrm{Al}-6 \mathrm{Zn} 2 \mathrm{Mg}-2 \mathrm{Cu}$ composites was studied. The cutting force and surface roughness were affected by feed rate (Ubeyli et al., 2011). Cutting force analysis plays a vital role in studying the machining process of FRP materials (Paulo Davim et al., 2009). Sreejith et al., (2007) observed that the cutting force and the cutting temperature affect the performance of the cutting tools while machining carbon/carbon composites. Chen (1997) correlated the delamination factor with the average thrust force only for Carbon Fiber Reinforced Plastic (CFRP) laminates and found it to behave linearly. He also studied the effect of various geometry parameters like point angle, helix angle chisel edge, and Web thickness and correlated them to the cutting forces. However, were not concluded effectively to predict delamination. Lee (2001) investigated the machinability of glass fiber reinforced plastics by means of different tool materials and geometries. Three parameters such as cutting speed, feed rate and depth of cut were selected and cutting force measurements were taken using the Kistler (9257B) piezoelectric dynamometer. Single crystal diamond, poly crystal diamond and cubic boron nitride were used for turning process. It was found that, the single crystal diamond tool is excellent for GFRP cutting. Rao et al. (2007) simulated orthogonal machining of unidirectional carbon fiber-reinforced polymer and glass fiber-reinforced polymer composites using finite element method. The cutting force was the response studied both for experimentally and numerically for a range of fiber orientations, depths of cut, and tool rake angles. Recent studies on unidirectional glass fiber composites revealed the chip formation mechanism in orthogonal cutting. In case of long oriented glass fiber, degradation of the matrix adjacent to the fiber occurs first, followed by failure of the fiber at its rear side (Rao et al., 2007). In orthogonal cutting process like turning, influence of fiber orientation, cutting parameters, tool geometry in GFRP has been studied (Mikaddem et al., 2008).

Chang (2008) presented a model to predict the cutting temperatures in turning of glass-fiber-reinforced plastics with chamfered main cutting edge sharp worn tools that can accurately predict the cutting temperatures and the cutting forces. Isik and Kentli (2009) proposed an approach for turning of a glass fiber reinforced plastic composites using cemented carbide tool. Three parameters such as depth of cut, cutting speed and feed rate were selected to minimize the tangential and feed force measurement. Weighting techniques was used. The idea of this technique consists in adding all the objective functions together using different coefficients for each. It means that we change our multicriteria optimization problem to a scalar optimization problem by creating one function. It was observed that, technique will be more economical to predict the effect of different influential combination of parameters. Mata et al. (2010) developed a cutting forces prediction model for the machining of carbon reinforced PEEK CF30 using response surface methodology by using Tin-coated cutting tool. Three parameters such as cutting speed, feed rate and depth of cut were selected to minimize the cutting forces. Authors concluded that, the experimental values agreed with the predicted results indicating suitability of the Multiple Regression models. Rusinek (2010) investigated the milling process of the epoxidepolymer matrix composite reinforced carbon fibers (EPMC - carbon composite). Diamond coated tool on milling machine was used and two parameters such as feed and rotational speed were selected ranging from 2000 to $8000 \mathrm{rpm}$ and feed from 200 to 720 $\mathrm{mm} / \mathrm{min}$. Piezoelectric dynamometer was used for measurement of feed and rotational speed. Hussain et al. (2010) developed a surface roughness prediction model for the machining of GFRP pipes using Response Surface Methodology by using carbide tool (K20). Four parameters such as cutting speed, feed rate, depth of cut and work piece (fiber orientation) were selected and the surface roughness was measured by using form taly surf tester. It was found that, the depth of cut shows a minimum effect on surface roughness as compared to other parameters. Rajasekaran et al., (2011) used fuzzy logic for modeling and prediction of CFRP work piece. Three parameters such as depth of cut, feed rate and cutting speed were selected and the surface roughness was measured by using TR200 hand-held tester. Cubic boron nitride tool was used for turning process. Scanning electron microscope was used for micrographs. It was found that the fuzzy logic modeling technique can be effectively used for the prediction of surface roughness in machining of CFRP composites.

Hussain et al. (2011) developed cutting power prediction model for turning of glass fiber reinforced plastics composite using response surface methodology. Carbide (K20), Cubic Boron Nitride (CBN) and Polycrystalline Diamond (PCD) tool on turning machine was used and four parameters such as cutting speed, fiber orientation angle, depth of cut and feed rate were selected. Author concluded that, lower power consumption was observed at low cutting speed, low feed, moderate depth of cut and low fiber orientation angle. PCD tool performing better compared to the other two tools used. Ntziantzias et al. (2011) used Kienzle- 
Victor model of GFRP work piece. Two parameters such as feed rate and cutting speed were selected to minimize the cutting forces measurements. Cemented carbide (P20) tool was used for turning process. Authors concluded that, the Kienzle-Victor modeling technique can be effectively used for the prediction of cutting forces in machining of GFRP composites. Khan et al., (2011) proposed an approach for turning of a glass fiber reinforced plastic composites using two different alumina cutting tools: namely, a Ti[C, N] mixed alumina cutting tool (CC650) and a SiC whisker reinforced alumina cutting tool (CC670). Three parameters such as cutting speed, depth of cut and feed rate were selected and the surface roughness was measured by using TR200 surface profilometer. It was found that the performance of the $\mathrm{SiC}$ whisker reinforced alumina cutting tool is better than that of the Ti[C, N] mixed alumina cutting tool while machining GFRP composite.

Hussain et al. (2011) developed a surface roughness and cutting force prediction model for the machining of GFRP tubes by using carbide tool (K20), cubic boron nitride (CBN) and polycrystalline diamond (PCD) using response surface methodology. Four parameters such as cutting speed, feed rate, depth of cut and work piece (fiber orientation) were selected to minimize the surface roughness and cutting forces. It was found that, the polycrystalline diamond (PCD) cutting tool is better than other two tools used. Kumar et al., (2012) developed a cutting force prediction model for the machining of UD-GFRP using regression modeling by using Polycrystalline diamond cutting tool. Three parameters such as cutting speed, depth of cut and feed rate were selected to minimize the cutting force. It was found that the depth of cut is the factor, which great influence on radial force, followed by has feed rate factor than other parameters, whilst feed rate is the least significant parameter. Also, Authors concluded that, the experimental values agreed with the predicted results indicating suitability of the Multiple Regression models. Kumar et al., (2012) investigated the turning process of the unidirectional glass fiber reinforced plastic (UD-GFRP) composites. polycrystalline diamond (PCD) tool on turning machine was used and six parameters such as tool nose radius, tool rake angle, feed rate, cutting speed, depth of cut and along with cutting environment (dry, wet and cooled (5-7 temperature)) on the surface roughness produced. It was found that the feed rate is the factor, which has great influence on surface roughness, followed by cutting speed.

This paper mainly focuses on finding optimum parameters considering the cutting forces of UD-GFRP rod. Experiments were conducted through the established Taguchi's design method. In this study, Taugchi's DOE approach is used to analyze the effect of turning process parameters - tool nose radius, tool rake angles, feed rate, cutting speed, cutting environment (dry, wet and cooled) and depth of cut, on the cutting forces by using PCD inserts. UD-GFRP has been considered for the optimization of multiple regression analysis. Finally, analysis of variance (ANOVA) and confirmation test have been conducted to validate the predicted values.

\section{Materials and Experimental Procedure}

In the present study, Pultrusion processed unidirectional glass fiber reinforced composite rods are used. Pultrusion process is an effective method to manufacture strong light weight composite materials. Fibers are pulled from spools through a device that coats them with a resin. They are then typically heat treated and cut to length. The word Pultrusion describes the method of moving the fibers through the machinery. The diameter of the rod taken is $42 \mathrm{~mm}$ and length $840 \mathrm{~mm}$. The fiber used in the rod is E-glass and resin used is epoxy and properties of material used are shown in Table 1. A NH22 lathe machine with $11 \mathrm{~kW}$ spindle power and maximum speed of 3000rpm was used to perform the experiments. The machining tests were carried out using dry, wet and cooled (using water - soluble cutting fluid) environment. Sufficient care was taken to remove the highly abrasive UD-GFRP machining chips by directing the coolant on the rod. The cutting environment (dry, wet and cooled) was set during the machining of the rod, so as to get a comparative assessment of the performance of cutting environment which has not been studied earlier. This is a specially designed array. An interaction is built in between the first two columns. This interaction information can be obtained without sacrificing any other column. Interactions between three-level columns are distributed more or less uniformly to all the other three-level columns, which permits investigation of main effects. The Taguchi's mixed level design was selected as it was decided to keep two levels of tool nose radius. The rest five parameters were studied at three levels. Two level parameter has 1 DOF, and the remaining five three level parameters have $10 \mathrm{DOF}$, i.e., the total DOF required will be $11[=(1 * 1+(5 * 2)]$. The most appropriate orthogonal array in this case is $\mathrm{L}_{18}\left(2^{1} * 3^{7}\right)$ OA with 17 [= 18-1] DOF. Standard $\mathrm{L}_{18}$ OA with the parameters assigned by using linear graphs is used. The unassigned columns will be treated as error (Logothetics, 2003). The $\mathrm{L}_{18}$ orthogonal array had eight columns and 18 rows, thus, six machining parameters were assign to the columns. Eighteen experiments equal to rows with various combination levels of the machining parameters was used. The orthogonality was preserved, even if two column of the array remained empty. The process parameters, their designated symbol and ranges are also given in Table 2 . The plan is made of 18 tests (array rows) in which the tool nose radius, tool rake angle, feed rate, cutting speed, cutting environment (dry, wet and cooled) and depth of cut was assigned to columns 1 to 6 respectively as shown in Table 3 . 
Table 1 Mechanical and Thermal Properties of the UD - GFRP Material are

\begin{tabular}{|c|c|c|c|}
\hline $\begin{array}{l}\text { Sr. } \\
\text { No. }\end{array}$ & Particular & Value & Unit \\
\hline 1 & Glass Content (by weight) & $75 \pm 5$ & $\%$ \\
\hline 2 & Epoxy Resin content (by weight) & $25 \pm 5$ & $\%$ \\
\hline 3 & Reinforcement, unidirectional & 'E’ Glass Roving & --- \\
\hline 4 & Water absorption & 0.07 & $\%$ \\
\hline 5 & Density & $1.95-2.1$ & $\mathrm{gm} / \mathrm{cc}$ \\
\hline 6 & Tensile Strength & 6500 or $(650)$ & $\mathrm{Kg} / \mathrm{cm}^{2}$ or $\left(\mathrm{N} / \mathrm{mm}^{2}\right)$ \\
\hline 7 & Compression Strength & 6000 or $(600)$ & $\mathrm{Kg} / \mathrm{cm}^{2}$ or $\left(\mathrm{N} / \mathrm{mm}^{2}\right)$ \\
\hline 8 & Shear Strength & 255 & $\mathrm{Kg} / \mathrm{cm}^{2}$ or $\left(\mathrm{N} / \mathrm{mm}^{2}\right)$ \\
\hline 9 & Modulus of elasticity & 3200 or $(320)$ & $\mathrm{Kg} / \mathrm{cm}^{2}$ or $\left(\mathrm{N} / \mathrm{mm}^{2}\right)$ \\
\hline 10 & Thermal Conductivity & 0.30 & $\mathrm{Kcal} / \mathrm{Mhc}^{\circ}$ \\
\hline 11 & Weight of Rod $840 \mathrm{~mm}$ in length & 2.300 & Kgs \\
\hline 12 & Electrical strength (Radial): & 3.5 & $\mathrm{KV} / \mathrm{mm}$ \\
\hline 13 & Working Temperature Class: & Class 'F' (155) & Centigrade \\
\hline 14 & Martens Heat Distortion Temperature & 210 & Centigrade \\
\hline \multirow[t]{2}{*}{15} & Test in oil : (1) At $20^{\circ} \mathrm{C}$ : & $20 \mathrm{KV} / \mathrm{cm}$ & \\
\hline & (2) At $100^{\circ} \mathrm{C}$ : & $\begin{array}{c}20 \mathrm{KV} / \mathrm{cm}(50 \mathrm{KV} / 25 \\
\mathrm{mm})\end{array}$ & $\mathrm{cm}$ \\
\hline
\end{tabular}

Table 2 Control Parameters and their Level

\begin{tabular}{|c|c|c|c|c|}
\hline \multirow{2}{*}{$\begin{array}{c}\text { Process } \\
\text { Parameters } \\
\text { Design }\end{array}$} & \multirow[t]{2}{*}{ Process Parameters } & \multicolumn{3}{|c|}{ Levels } \\
\hline & & Low & Medium & High \\
\hline A & Tool nose Radius / mm & 0.4 & 0.8 & NIL \\
\hline B & Tool Rake angle / Degree & -6 & 0 & +6 \\
\hline $\mathrm{C}$ & Feed rate / (mm/rev.) & 0.05 & 0.1 & 0.2 \\
\hline $\mathrm{D}$ & Cutting speed $/(\mathrm{m} / \mathrm{min}). \& \mathrm{rpm}$ & (55.42) 420 & (110.84) 840 & (159.66) 1210 \\
\hline E & Cutting environment & Dry (1) & Wet (2) & Cooled (3) \\
\hline $\mathrm{F}$ & Depth of cut / mm & 0.2 & 0.8 & 1.4 \\
\hline
\end{tabular}

Table 3 Orthogonal Array $\mathrm{L}_{18}$ of Taguchi along with assigned Value

\begin{tabular}{|c|c|c|c|c|c|c|}
\hline $\begin{array}{c}\text { Expt. } \\
\text { No. }\end{array}$ & $\begin{array}{c}\text { Tool nose } \\
\text { Radius } \\
\text { /mm (A) }\end{array}$ & $\begin{array}{c}\text { Tool Rake } \\
\text { Angle } / \\
\text { Degree (B) }\end{array}$ & $\begin{array}{c}\text { Feed Rate / } \\
(\mathrm{mm} / \mathrm{rev} .) \\
(\mathrm{C})\end{array}$ & $\begin{array}{c}\text { Cutting Speed } / \\
(\mathrm{m} / \mathrm{min}) \& \mathrm{rpm} \\
(\mathrm{D})\end{array}$ & $\begin{array}{c}\text { Cutting } \\
\text { Environment } \\
(\mathrm{E})\end{array}$ & $\begin{array}{c}\text { Depth of } \\
\text { Cut/ mm } \\
(\mathrm{F})\end{array}$ \\
\hline 1 & 0.4 & $-6^{\circ}$ & 0.05 & $(55.42) 420$ & Dry (1) & 0.2 \\
2 & 0.4 & $-6^{\circ}$ & 0.1 & $(110.84) 840$ & Wet (2) & 0.8 \\
3 & 0.4 & $-6^{\circ}$ & 0.2 & $(159.66) 1210$ & Cooled (3) & 1.4 \\
4 & 0.4 & $0^{\circ}$ & 0.05 & $(55.42) 420$ & Wet (2) & 0.8 \\
5 & 0.4 & $0^{\circ}$ & 0.1 & $(110.84) 840$ & Cooled (3) & 1.4 \\
6 & 0.4 & $0^{\circ}$ & 0.2 & $(159.66) 1210$ & Dry (1) & 0.2 \\
7 & 0.4 & $+6^{\circ}$ & 0.05 & $(110.84) 840$ & Dry (1) & 1.4 \\
8 & 0.4 & $+6^{\circ}$ & 0.1 & $(159.66) 1210$ & Wet (2) & 0.2 \\
9 & 0.4 & $+6^{\circ}$ & 0.2 & $(55.42) 420$ & Cooled (3) & 0.8 \\
10 & 0.8 & $-6^{\circ}$ & 0.05 & $(159.66) 1210$ & Cooled (3) & 0.8 \\
11 & 0.8 & $-6^{\circ}$ & 0.1 & $(55.42) 420$ & Dry (1) & 1.4 \\
12 & 0.8 & $-6^{\circ}$ & 0.2 & $(110.84) 840$ & Wet (2) & 0.2 \\
13 & 0.8 & $0^{\circ}$ & 0.05 & $(110.84) 840$ & Cooled (3) & 0.2 \\
14 & 0.8 & $0^{\circ}$ & 0.1 & $(159.66) 1210$ & Dry (1) & 0.8 \\
15 & 0.8 & $0^{\circ}$ & 0.2 & $(55.42) 420$ & Wet (2) & 1.4 \\
16 & 0.8 & $+6^{\circ}$ & 0.05 & $(159.66) 1210$ & Wet (2) & 1.4 \\
17 & 0.8 & $+6^{\circ}$ & 0.1 & $(55.42) 420$ & Cooled (3) & 0.2 \\
18 & 0.8 & $+6^{\circ}$ & 0.2 & $(110.84) 840$ & Dry (1) & 0.8 \\
\hline
\end{tabular}


Table 4: Tool Geometries

\begin{tabular}{|l|l|}
\hline Clearance angle & $7^{\circ}$ \\
Grade & $\mathrm{M} 10$ \\
Cutting edge inclination angle Top Clearance & $7^{\circ}$ \\
Front Clearance & $10^{\circ}$ \\
Tool nose radius & 0.4 and $0.8 \mathrm{~mm}$ \\
Tool rake angles & $-6^{\circ}, 0^{\circ},+6^{\circ}$ and \\
& $-6^{\circ}, 0^{\circ},+6^{\circ}$ \\
\hline
\end{tabular}

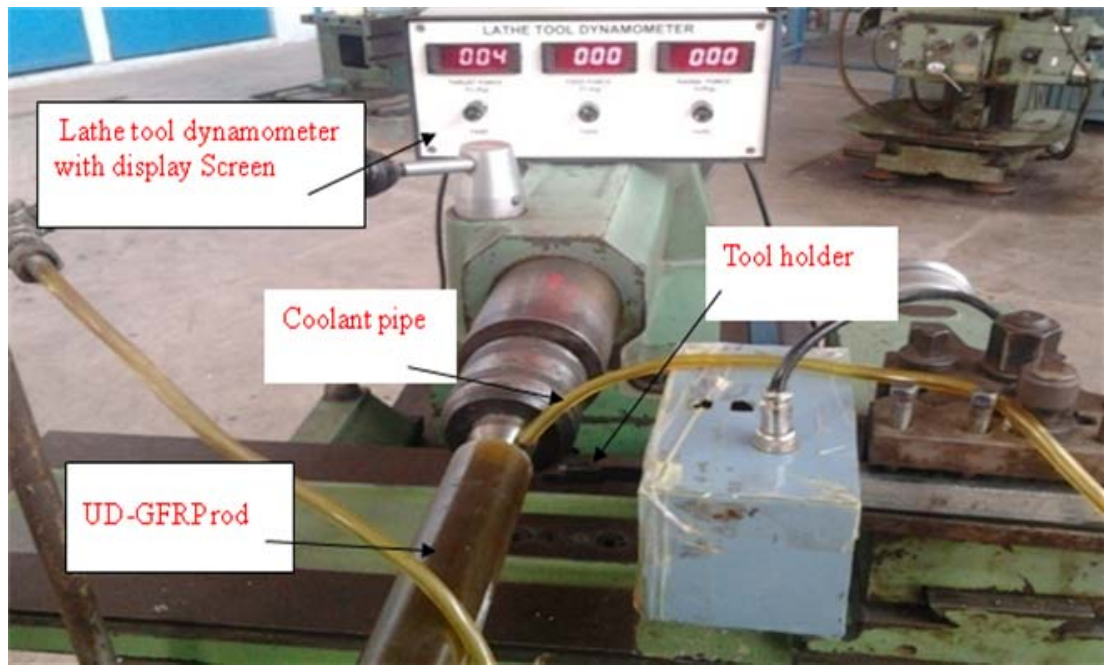

Figure 1: Experimental Setup

The geometry of the cutting tool VNMG insert is as follow: NQA BS EN ISO 9001-2000, rake angle $\left[-6^{\circ}\right.$ (negative), $0^{\circ},+6^{\circ}$ (positive)], clearance angle $7^{\circ}$, front Clearance $10^{\circ}$ and nose radius $0.4 \mathrm{~mm} \& 0.8 \mathrm{~mm}$ are as shown in Table 4 . Type SVJCR steel EN47 tool holder was used. The three components of the cutting forces for different cutting conditions were measured using a high precision, three point lathe tool type dynamometer as shown in Figure 1. Each experiment was repeated three times.

\section{Results and Discussion}

MINITAB statistical software was used for the analysis of the experimental work. The MINITAB software studies the experimental data and then provides the calculated results of signal-to-noise ratio. The effect of different process parameters on forces was calculated and plotted as the process parameters changes from one level to another. The average value of $\mathrm{S} / \mathrm{N}$ ratios is calculated to find out the effects of different parameters. Table 5 gives the experimental results for the average cutting force and their corresponding $\mathrm{S} / \mathrm{N}$ ratio using Taguchi $\mathrm{L}_{18}$ orthogonal array and measured values of tangential, feed and radial force for three different trial runs.

The minimum tangential force of $3.00 \mathrm{Kgs}$ was achieved in trial 1 at tool nose radius $(0.4 \mathrm{~mm})$, tool rake angle $\left(-6^{\circ}\right)$, feed rate $(0.05 \mathrm{~mm} / \mathrm{rev})$, cutting speed $(55.42) \mathrm{m} / \mathrm{min})$, dry cutting environment and depth of cut $(0.2 \mathrm{~mm})$. Generally, at the combination of lowest level of tool nose radius, tool rake angle, feed rate, cutting speed, dry cutting environment and depth of cut resulted in better tangential force. The highest tangential force of $11.93 \mathrm{Kgs}$ was obtained with trial 15 , at the largest tool nose radius $(0.8 \mathrm{~mm})$, moderate tool rake angle of $\left(-0^{\circ}\right)$, largest feed rate $(0.2 \mathrm{~mm} / \mathrm{rev})$, lowest cutting speed $(55.42 \mathrm{~m} / \mathrm{min})$, wet cutting environment and the largest depth of cut $(1.4 \mathrm{~mm})$.

The minimum feed force of $2.00 \mathrm{Kgs}$ was achieved in trial 1 at tool nose radius $(0.4 \mathrm{~mm})$, tool rake angle $\left(-6^{\circ}\right)$, feed rate $(0.05$ $\mathrm{mm} / \mathrm{rev})$, cutting speed $(55.42 \mathrm{~m} / \mathrm{min})$, dry cutting environment and depth of cut $(0.2 \mathrm{~mm})$. The lowest level of tool nose radius, tool rake angle, feed rate, cutting speed, depth of cut and dry cutting environment resulted in better feed force. The highest feed force of $10.00 \mathrm{Kgs}$ was obtained with trial 15 , at the largest tool nose radius $(0.8 \mathrm{~mm})$, moderate tool rake angle $\left(0^{\circ}\right)$, largest feed rate $(0.2 \mathrm{~mm} / \mathrm{rev})$, lowest cutting speed $(55.42 \mathrm{~m} / \mathrm{min})$, wet cutting environment and the largest depth of cut $(1.4 \mathrm{~mm})$.

The minimum radial force of $1.80 \mathrm{Kgs}$ was achieved in trial 1 at tool nose radius $(0.4 \mathrm{~mm})$, tool rake angle $\left(-6^{\circ}\right)$, feed rate $(0.05$ $\mathrm{mm} / \mathrm{rev})$, cutting speed $(55.42 \mathrm{~m} / \mathrm{min}$.), dry cutting environment and depth of cut $(0.2 \mathrm{~mm})$. Generally, the lowest level of tool nose radius, tool rake angle, feed rate, cutting speed, depth of cut and dry cutting environment resulted in better radial force. The highest radial force of $6.00 \mathrm{Kgs}$ was obtained with trial 15 , at the largest tool nose radius $(0.8 \mathrm{~mm})$, moderate tool rake angle $\left(0^{\circ}\right)$, 
largest feed rate $(0.2 \mathrm{~mm} / \mathrm{rev}$.$) , lowest cutting speed (55.42 \mathrm{~m} / \mathrm{min}$.), wet cutting environment and the largest depth of cut (1.4 $\mathrm{mm})$.

Table 5 Test Data Summary for Tangential, Feed and Radial force

\begin{tabular}{|c|c|c|c|c|c|c|c|c|c|c|c|c|c|c|c|}
\hline \multirow{2}{*}{$\begin{array}{l}\text { Expt. } \\
\text { No. }\end{array}$} & \multicolumn{3}{|c|}{ Tangential Force $\left(F_{t}\right)$} & \multirow{2}{*}{$\begin{array}{c}\text { Average } \\
\mathrm{F}_{\mathrm{t}} \\
(\mathrm{Kg})\end{array}$} & \multirow{2}{*}{$\begin{array}{c}\mathrm{S} / \mathrm{N} \text { ratio } \\
(\mathrm{dB})\end{array}$} & \multicolumn{3}{|c|}{ Feed Force $\left(F_{f}\right)$} & \multirow{2}{*}{$\begin{array}{c}\text { Average } \\
F_{\mathrm{f}} \\
(\mathrm{Kg})\end{array}$} & \multirow{2}{*}{$\begin{array}{c}\mathrm{S} / \mathrm{N} \text { ratio } \\
(\mathrm{dB})\end{array}$} & \multicolumn{3}{|c|}{ Radial Force $\left(F_{r}\right)$} & \multirow{2}{*}{$\begin{array}{c}\text { Average } \\
\left(\mathrm{F}_{\mathrm{r}}\right) \\
(\mathrm{Kg})\end{array}$} & \multirow{2}{*}{$\begin{array}{l}\mathrm{S} / \mathrm{N} \text { ratio } \\
(\mathrm{dB})\end{array}$} \\
\hline & $\mathrm{Ft}_{1}$ & $\mathrm{Ft}_{2}$ & $\mathrm{Ft}_{3}$ & & & $\overline{F f_{1}}$ & $\mathrm{Ff}_{2}$ & $\mathrm{Ff}_{3}$ & & & $\mathrm{Fr}_{1}$ & $\mathrm{Fr}_{2}$ & $\mathrm{Fr}_{3}$ & & \\
\hline 1 & 3.00 & 3.50 & 3.80 & 3.43 & -10.75 & 2 & 2.3 & 2.20 & 2.17 & -10.75 & 2.11 & 1.80 & 1.90 & 1.94 & -6.73 \\
\hline 2 & 6.20 & 7.22 & 7.50 & 6.97 & -16.90 & 4.9 & 5.8 & 5.4 & 5.37 & -16.90 & 4.55 & 4.29 & 4.49 & 4.44 & -14.61 \\
\hline 3 & 8.40 & 8.50 & 8.20 & 8.37 & -18.45 & 6.50 & 6.80 & 7.00 & 6.77 & -18.45 & 5.90 & 5.70 & 5.43 & 5.68 & -16.61 \\
\hline 4 & 3.80 & 5.50 & 4.50 & 4.60 & -13.35 & 3.40 & 3.60 & 4.00 & 3.67 & -13.35 & 3.10 & 3.39 & 3.68 & 3.39 & -11.31 \\
\hline 5 & 7.90 & 7.50 & 9.00 & 8.13 & -18.23 & 6.00 & 5.50 & 5.30 & 5.60 & -18.23 & 4.22 & 4.60 & 4.73 & 4.52 & -14.98 \\
\hline 6 & 3.30 & 3.67 & 4.00 & 3.66 & -11.29 & 2.70 & 3.00 & 2.90 & 2.87 & -11.29 & 2.20 & 2.20 & 2.00 & 2.13 & -9.16 \\
\hline 7 & 5.25 & 7.00 & 6.33 & 6.19 & -15.90 & 4.90 & 4.70 & 5.00 & 4.87 & -15.90 & 3.30 & 3.30 & 3.10 & 3.23 & -13.75 \\
\hline 8 & 4.50 & 4.98 & 4.00 & 4.49 & -13.09 & 2.9 & 3.1 & 3.0 & 3.00 & -13.09 & 2.83 & 2.68 & 2.14 & 2.55 & -9.55 \\
\hline 9 & 7.00 & 7.70 & 6.70 & 7.13 & -17.08 & 5.20 & 5.40 & 5.60 & 5.40 & -17.08 & 3.83 & 3.98 & 4.15 & 3.99 & -14.65 \\
\hline 10 & 6.60 & 8.80 & 8.00 & 7.80 & -17.90 & 6.40 & 6.70 & 7.10 & 6.73 & -17.90 & 4.82 & 4.62 & 4.32 & 4.59 & -16.57 \\
\hline 11 & 9.60 & 9.97 & 10.80 & 10.12 & -20.12 & 8.50 & 9.00 & 8.60 & 8.70 & -20.12 & 5.60 & 5.80 & 5.80 & 5.73 & -18.79 \\
\hline 12 & 4.10 & 4.00 & 3.70 & 3.93 & -11.90 & 3.70 & 4.00 & 3.80 & 3.83 & -11.90 & 2.20 & 2.00 & 1.90 & 2.03 & -11.68 \\
\hline 13 & 4.00 & 4.50 & 4.10 & 4.20 & -12.48 & 3.78 & 4.0 & 3.90 & 3.89 & -12.48 & 2.69 & 2.97 & 2.60 & 2.75 & -11.81 \\
\hline 14 & 7.50 & 8.44 & 8.50 & 8.15 & -18.23 & 7.00 & 6.80 & 6.60 & 6.80 & -18.23 & 4.38 & 4.88 & 4.14 & 4.47 & -16.65 \\
\hline 15 & 11.40 & 11.66 & 11.93 & 11.66 & -21.34 & 9.50 & 9.60 & 10.00 & 9.70 & -21.34 & 5.90 & 5.90 & 6.00 & 5.93 & -19.74 \\
\hline 16 & 7.25 & 8.60 & 6.85 & 7.57 & -17.62 & 7.90 & 7.70 & 8.20 & 7.93 & -17.62 & 4.50 & 4.80 & 4.00 & 4.43 & -17.99 \\
\hline 17 & 4.70 & 3.33 & 3.40 & 3.81 & -11.74 & 2.96 & 3.8 & 3.2 & 3.32 & -11.74 & 2.30 & 2.00 & 2.51 & 2.27 & -10.47 \\
\hline 18 & 9.74 & 10.22 & 10.00 & 9.99 & -19.99 & 8.40 & 8.00 & 8.20 & 8.20 & -19.99 & 5.42 & 4.96 & 5.15 & 5.18 & -18.28 \\
\hline
\end{tabular}

These values of $\mathrm{S} / \mathrm{N}$ ratio and means will then further be analysed to detect the most responsible factor and the percentage contribution of each factor. The effects are shown by both tables and graphs. Regression analyses are applied to identify the best levels of cutting parameters and their significance. Taguchi recommends the use of S/N ratio to measure the quality characteristics deviating from the desired values. The quality characteristic in cutting forces is taken as Lower the better type. The $\mathrm{S} / \mathrm{N}$ ratio for the Lower the better type of response can be computed (Ross, 1988 and Roy, 1990) as:

Smaller the better:

$$
\mathrm{S} / \mathrm{N}=-10 \log \frac{1}{n} \sum y^{2}
$$

where $\mathrm{n}$ is the number of observations, $\mathrm{y}$ is the observed data.

The pooled ANOVA of the tangential force (raw data) is given in Table 6(A). It is evident from the pooled ANOVA for the raw data that tool nose radius, feed rate and depth of cut are significant and thus affect the variation and average value of the tangential force. The percent contribution of parameters as shown in Table 6(A) reveals that the influence of depth of cut in affecting tangential force is significantly larger followed by that of tool nose radius, feed rate and cutting environment. The tool rake angle and cutting speed has little influence on tangential force. The S/N pooled ANOVA is given in Table 6(B). It is evident from the pooled ANOVA for the $\mathrm{S} / \mathrm{N}$ data that depth of cut is significant and thus affects the variation and average value of the tangential force.

The response graph for the average response data of tangential force (mean and $\mathrm{S} / \mathrm{N}$ ratio) are plotted in Figure 2. It is evident from the Figure 2 that the tangential force is minimum at $1^{\text {st }}$ level of tool nose radius (A1), $3^{\text {rd level }}$ of tool rake angles (B3), $1^{\text {st }}$ level of feed rate (C1), $2^{\text {nd }}$ level of cutting speed (D2), $2^{\text {nd }}$ level of cutting environment, under wet condition (E2) and $1^{\text {st }}$ level of depth of cut (F1). The S/N plots in Figure 2 reveal that tangential force is minimum at A2-B1-C3-D3-E1-F3. Figure 2 shows the response graph of tangential force. The results indicated that the tangential force decreases with decrease in tool nose radius, feed rate, depth of cut and decreases with increase in tool rake angle, cutting speed and cutting environment. 
Table 6 (A) ANOVA Results for Tangential force (Raw Data)

\begin{tabular}{|c|c|c|c|c|c|c|c|}
\hline Source & SS & DOF & $\mathrm{V}$ & F ratio & Prob. & $\mathrm{SS}^{\prime}$ & $\mathrm{P}(\%)$ \\
\hline Tool nose radius(A) & 33.828 & 1 & 33.828 & $28.05^{*}$ & 0.000 & 32.622 & 9.65 \\
\hline Tool rake angle(B) & 0.604 & 2 & 0.302 & Pooled & 0.780 & --- & --- \\
\hline Feed rate $(\mathrm{C})$ & 31.899 & 2 & 15.949 & $13.22 *$ & 0.000 & 29.487 & 8.72 \\
\hline Cutting speed(D) & 0.452 & 2 & 0.226 & Pooled & 0.830 & --- & --- \\
\hline Cutting Environment(E) & 1.630 & 2 & 0.815 & Pooled & 0.514 & --- & --- \\
\hline Depth of $\operatorname{cut}(F)$ & 219.004 & 2 & 109.502 & $90.79 *$ & 0.000 & 216.592 & 64.07 \\
\hline $\begin{array}{l}\mathrm{T} \\
\mathrm{e}(\text { pooled })\end{array}$ & $\begin{array}{l}338.073 \\
50.656\end{array}$ & $\begin{array}{l}53 \\
42\end{array}$ & 1.206 & & & $\begin{array}{l}338.073 \\
63.922\end{array}$ & $\begin{array}{l}100.00 \\
18.91\end{array}$ \\
\hline
\end{tabular}

Table 6 (B) ANOVA Results for Tangential force (S/N Ratio)

\begin{tabular}{|l|c|c|c|c|c|c|c|}
\hline \multicolumn{1}{|c|}{ Source } & SS & DOF & V & F ratio & Prob. & SS & P (\%) \\
\hline Tool nose radius(A) & 14.715 & 1 & 14.715 & Pooled & 0.058 & --- & --- \\
Tool rake angle(B) & 0.102 & 2 & 0.051 & Pooled & 0.981 & -- & --- \\
Feed rate(C) & 14.128 & 2 & 7.064 & Pooled & 0.152 & --- & --- \\
Cutting speed(D) & 0.404 & 2 & 0.202 & Pooled & 0.928 & --- & --- \\
Cutting Environment(E) & 0.407 & 2 & 0.203 & Pooled & 0.928 & -- & --- \\
Depth of cut(F) & 152.113 & 2 & 76.056 & $28.27^{*}$ & 0.001 & 146.731 & 74.10 \\
& & & & & & & \\
\cline { 2 - 5 } T & 198.013 & 17 & & & & 198.013 & 100.00 \\
e (pooled) & 16.145 & 6 & 2.691 & & & 45.746 & 23.10 \\
\hline
\end{tabular}

$\mathrm{SS}=$ sum of squares, $\mathrm{DOF}=$ degrees of freedom, variance $(\mathrm{V})=(\mathrm{SS} / \mathrm{DOF}), \mathrm{T}=$ total, Prob. $=$ Probability, $\mathrm{SS}=$ pure sum of squares, $\mathrm{P}=$ percent contribution, $\mathrm{e}=$ error, $\mathrm{F}_{\text {ratio }}=(\mathrm{V} /$ error $)$, Tabulated $F$-ratio at $95 \%$ confidence level

* Significant at $95 \%$ confidence level

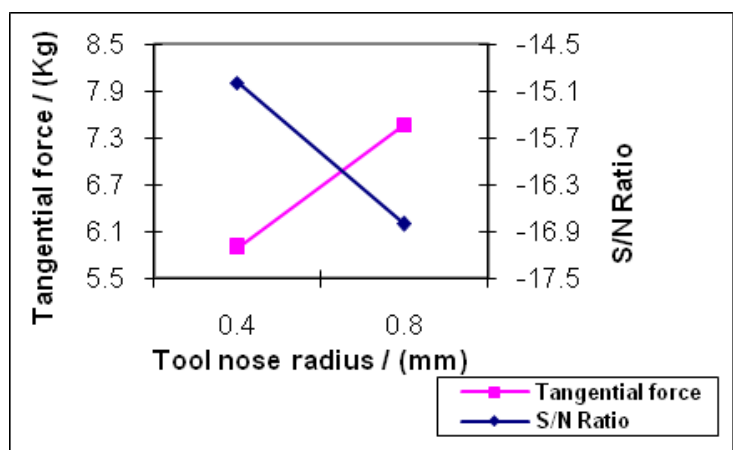

(a)

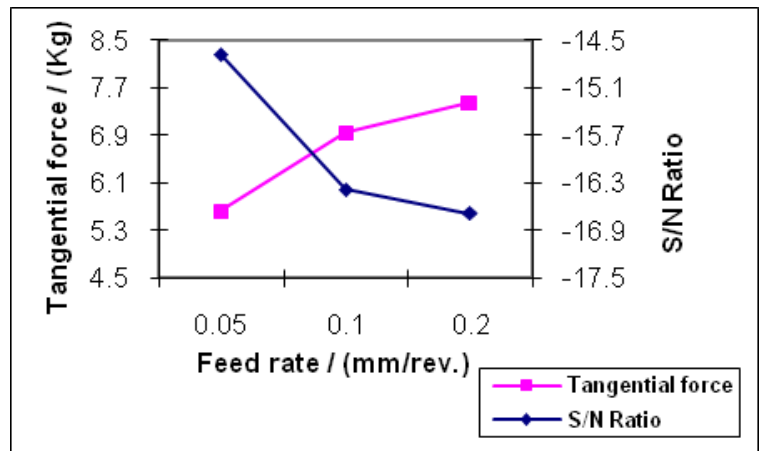

(c)

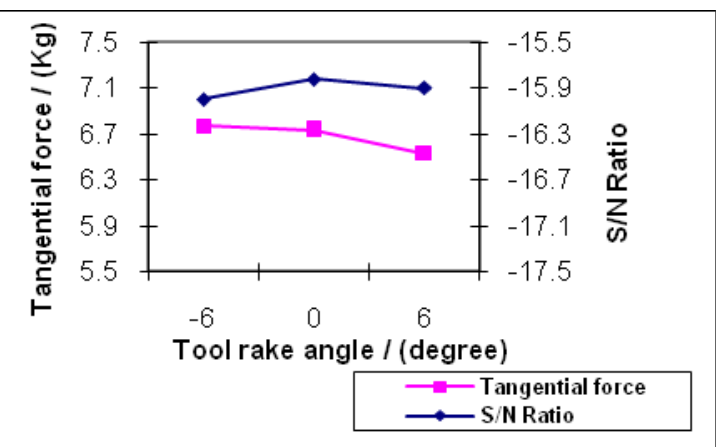

(b)

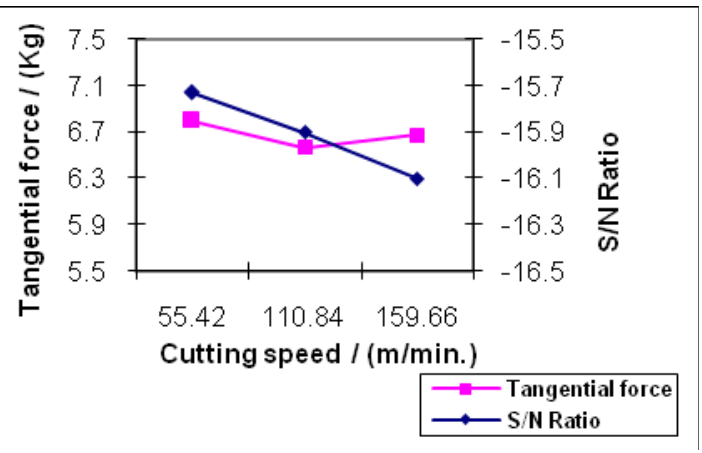

(d)

Figure: 2 Response and S/N ratio (a) effect of nose radius, (b) effect of tool rake angle, (c) effect of feed rate, (d) effect of cutting speed. 


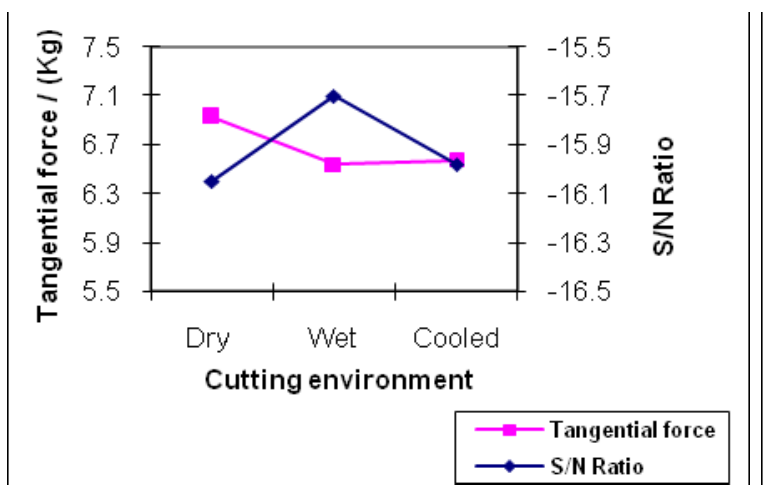

(e)

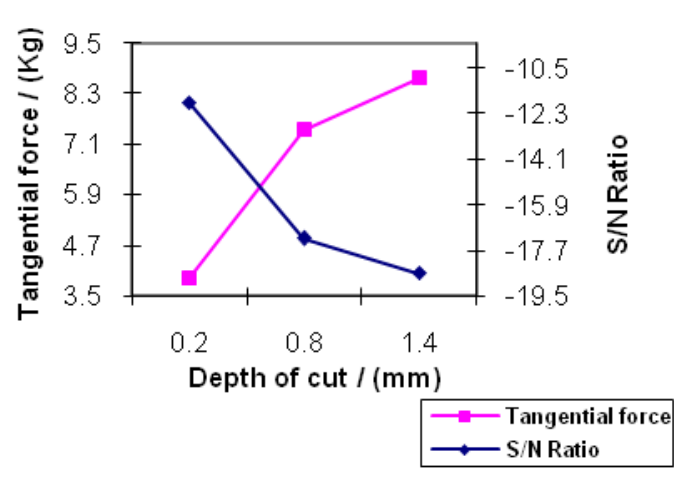

(f)

Figure 2: Response and S/N ratio (e) effect of cutting environment, (f) effect of depth of cut.

The pooled ANOVA of the feed force (raw data) is given in Table 7(A). The S/N pooled ANOVA is given in Table 7(B). It is evident from the pooled ANOVAs for the raw data and $\mathrm{S} / \mathrm{N}$ data that tool nose radius, feed rate and depth of cut are significant in both and thus affect the variation and average value of the feed force. The percent contribution of parameters as shown in Table 7(A) reveals that the influence of depth of cut in affecting feed force is significantly larger followed by that of tool nose radius, feed rate and cutting speed. Cutting environment and tool rake angle has little influence on feed force.

The response graph for the average response data of feed force (mean) are also formed and are plotted in Figure 3. Optimum combination to get the low value of feed force is A1-B2-C1-D2-E3-F1 where A, B, C, D, E and F are tool nose radius, tool rake angle, feed rate, cutting speed, cutting environment parameters (dry, wet and cooled) and depth of cut respectively and 1, 2 and 3 are the three levels (low, medium and high value, respectively) of these parameters within the test range. The $\mathrm{S} / \mathrm{N}$ plots in Figure 3 reveal that feed force is minimum at A2-B1-C3-D3-E3-F3. Response graph shows due feed force decreases with decrease in tool nose radius, feed rate, depth of cut and increases with increase in cutting speed. The results indicated that the feed force decreases with increase in tool rake angle and increase with decreases in cutting environment.

Table 7 (A) ANOVA Results for Feed force (Raw Data)

\begin{tabular}{|l|c|c|c|c|c|c|c|}
\hline \multicolumn{1}{|c|}{ Source } & SS & DOF & V & F ratio & Prob. & SS & P (\%) \\
\hline Tool nose radius(A) & 62.813 & 1 & 62.813 & $151.83^{*}$ & 0.000 & 62.399 & 24.49 \\
Tool rake angle(B) & 0.306 & 2 & 0.153 & Pooled & 0.693 & --- & --- \\
Feed rate(C) & 14.105 & 2 & 7.052 & $17.05^{*}$ & 0.000 & 13.277 & 5.21 \\
Cutting speed(D) & 1.369 & 2 & 0.685 & Pooled & 0.203 & --- & --- \\
Cutting Environment(E) & 1.127 & 2 & 0.563 & Pooled & 0.267 & --- & --- \\
Depth of cut(F) & 157.719 & 2 & 78.859 & $190.61^{*}$ & 0.000 & 156.891 & 61.57 \\
& & & & & & & \\
\cline { 2 - 5 } T (pooled) & 254.814 & 53 & & & & 254.814 & 100.00 \\
e & 17.376 & 42 & 0.414 & & & 21.93 & 8.61 \\
\hline
\end{tabular}

Table 7 (B) ANOVA Results for Feed force (S/N Ratio)

\begin{tabular}{|l|c|c|c|c|c|c|c|}
\hline \multicolumn{1}{|c|}{ Source } & SS & DOF & V & F ratio & Prob. & SS $^{\prime}$ & P (\%) \\
\hline Tool nose radius(A) & 52.170 & 1 & 52.170 & $45.91^{*}$ & 0.001 & 51.034 & 21.41 \\
Tool rake angle(B) & 0.170 & 2 & 0.085 & Pooled & 0.929 & --- & --- \\
Feed rate(C) & 12.003 & 2 & 6.001 & $5.28^{*}$ & 0.048 & 9.731 & 4.08 \\
Cutting speed(D) & 2.061 & 2 & 1.031 & Pooled & 0.453 & --- & --- \\
Cutting Environment(E) & 0.297 & 2 & 0.149 & Pooled & 0.880 & -- & --- \\
Depth of cut(F) & 164.876 & 2 & 82.438 & $72.54^{*}$ & 0.000 & 162.604 & 68.21 \\
& & & & & & & \\
\cline { 2 - 6 } T & 238.396 & 17 & & & & 238.396 & 100.00 \\
e (pooled) & 6.819 & 6 & 1.136 & & & 19.315 & 8.10 \\
\hline
\end{tabular}

$\mathrm{SS}=$ sum of squares, $\mathrm{DOF}=$ degrees of freedom, variance $(\mathrm{V})=(\mathrm{SS} / \mathrm{DOF}), \mathrm{T}=$ total, Prob. $=$ Probability, $\mathrm{SS}^{\prime}=$ pure sum of squares, $\mathrm{P}=$ percent contribution, $\mathrm{e}=$ error, $\mathrm{F}_{\text {ratio }}=(\mathrm{V} / \mathrm{error})$, Tabulated $F$-ratio at $95 \%$ confidence level

* Significant at $95 \%$ confidence level. 


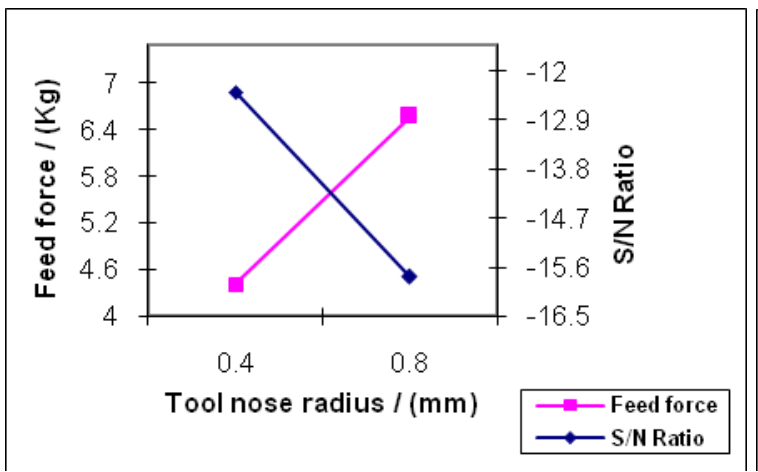

(a)

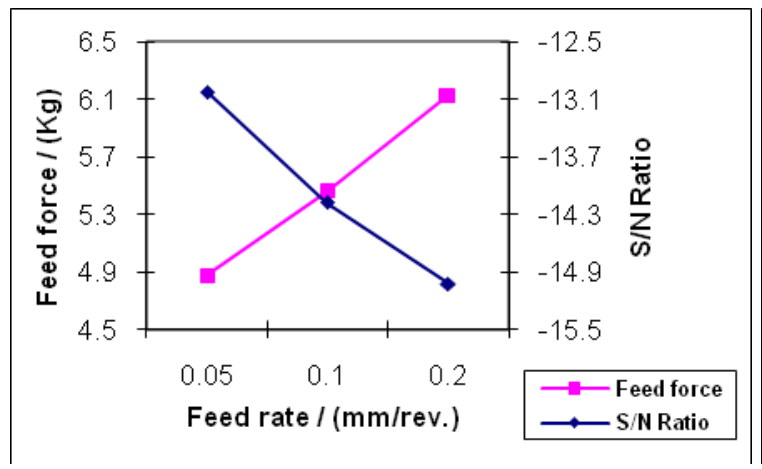

(c)

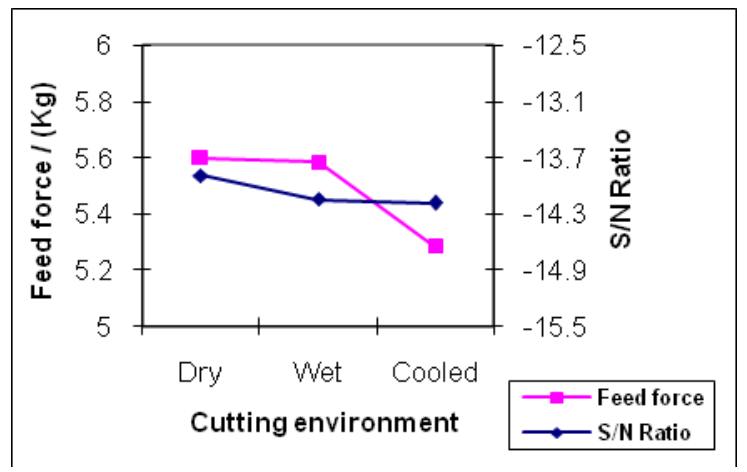

(e)

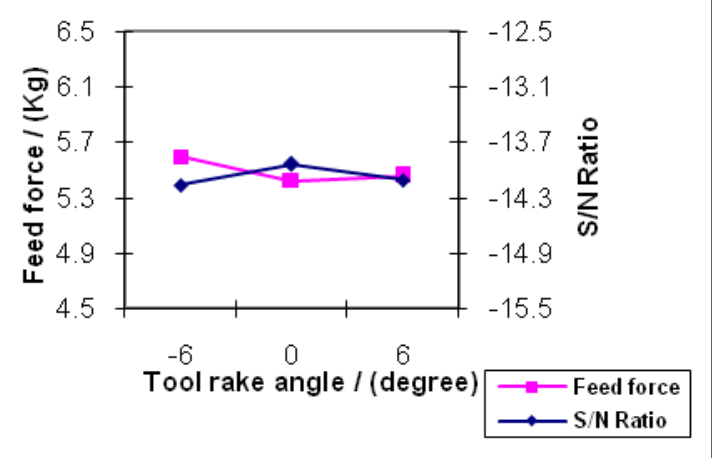

(b)

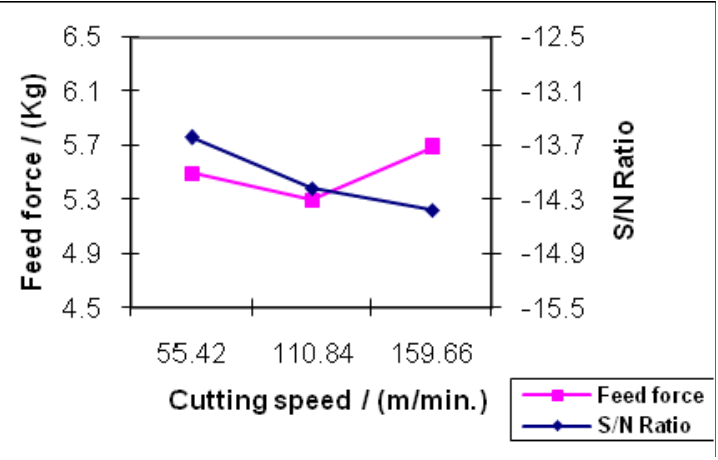

(d)

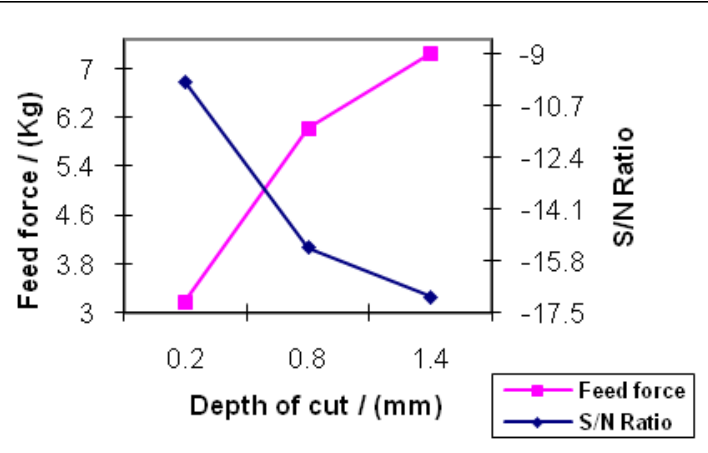

(f)

Figure: 3 Response and $\mathrm{S} / \mathrm{N}$ ratio (a) effect of nose radius, (b) effect of tool rake angle, (c) effect of feed rate, (d) effect of cutting speed, (e) effect of cutting environment, (f) effect of depth of cut.

The pooled ANOVA of the radial force (raw data) is given in Table 8(A). It is evident from the pooled ANOVA for the raw data that tool nose radius, tool rake angle, feed rate and depth of cut are significant and thus affect the variation and average value of the radial force. The percent contribution of parameters as shown in Table 8(A) reveals that the influence of depth of cut in affecting radial force is significantly larger followed by that of tool nose radius, feed rate, tool rake angle and cutting speed. The cutting environment has little influence on radial force. The S/N pooled ANOVA is given in Table 8(B). It is evident from the pooled ANOVA for the $\mathrm{S} / \mathrm{N}$ data that depth of cut is significant and thus affects the variation and average value of the radial force. Figure 4 shows the response graph of radial force. Based on the response graph optimal conditions is A1-B3-C1-D2-E1-F1. The $\mathrm{S} / \mathrm{N}$ plots in Figure 4 reveal that radial force is minimum at $2^{\text {nd }}$ level of tool nose radius (A2), $1^{\text {st }}$ level of tool rake angles (B1), $3^{\text {rd }}$ level of feed rate (C3), $3^{\text {rd }}$ level of cutting speed (D3), $3^{\text {rd }}$ level of cutting environment, under cooled condition (E3) and $3^{\text {rd }}$ level of depth of cut (F3). Response graph shows the radial force decreases with decrease in tool nose radius, feed rate, cutting environment, depth of cut and increases with increase in cutting speed. The results indicated that the radial force increase with decrease in tool rake angle. 
Table 8 (A) ANOVA Results for Radial force (Raw Data)

\begin{tabular}{|l|c|c|c|c|c|c|c|}
\hline \multicolumn{1}{|c|}{ Source } & SS & DOF & V & F ratio & Prob. & SS & P (\%) \\
\hline Tool nose radius(A) & 5.0784 & 1 & 5.0784 & $18.63^{*}$ & 0.000 & 4.8058 & 5.07 \\
Tool rake angle(B) & 1.9133 & 2 & 0.9566 & $3.51^{*}$ & 0.039 & 1.3681 & 1.44 \\
Feed rate(C) & 5.9069 & 2 & 2.9534 & $10.83^{*}$ & 0.000 & 5.3617 & 5.65 \\
Cutting speed(D) & 0.7346 & 2 & 0.3673 & Pooled & 0.271 & --- & --- \\
Cutting Environment(E) & 0.3760 & 2 & 0.1880 & Pooled & 0.507 & -- & -- \\
Depth of cut(F) & 69.4015 & 2 & 34.7008 & $127.29^{*}$ & 0.000 & 68.8563 & 72.59 \\
& & & & & & & \\
\cline { 2 - 5 } $\mathrm{T}$ & 94.8600 & 53 & & & & 94.8600 & 100.00 \\
e (pooled) & 11.4494 & 42 & 0.2726 & & & 14.448 & 15.23 \\
\hline
\end{tabular}

Table 8 (B) ANOVA Results for Radial force (S/N Ratio)

\begin{tabular}{|c|c|c|c|c|c|c|c|}
\hline Source & SS & DOF & $\mathrm{V}$ & F ratio & Prob. & $\mathrm{SS}^{\prime}$ & $\mathrm{P}(\%)$ \\
\hline Tool nose radius(A) & 7.685 & 1 & 7.685 & Pooled & 0.143 & --- & --- \\
\hline Tool rake angle(B) & 1.188 & 2 & 0.594 & Pooled & 0.809 & --- & --- \\
\hline Feed rate $(C)$ & 7.151 & 2 & 3.575 & Por & 0.335 & --- & --- \\
\hline Cutting speed(D) & 1.185 & 2 & 0.593 & Pooled & 0.809 & --- & --- \\
\hline Cutting Environment(E) & 1.688 & 2 & 0.844 & Pooled & 0.743 & --- & --- \\
\hline Depth of $\operatorname{cut}(F)$ & 149.866 & 2 & 74.933 & $27.69 *$ & 0.001 & 144.454 & 78.08 \\
\hline $\begin{array}{l}\mathrm{T} \\
\mathrm{e}(\text { pooled })\end{array}$ & $\begin{array}{c}185.001 \\
16.238\end{array}$ & $\begin{array}{c}17 \\
6\end{array}$ & 2.706 & & & $\begin{array}{l}185.001 \\
46.004\end{array}$ & $\begin{array}{l}100.00 \\
2487\end{array}$ \\
\hline
\end{tabular}

$\mathrm{SS}=$ sum of squares, $\mathrm{DOF}=$ degrees of freedom, variance $(\mathrm{V})=(\mathrm{SS} / \mathrm{DOF}), \mathrm{T}=$ total, Prob. $=$ Probability, $\mathrm{SS}^{\prime}=$ pure sum of squares, $\mathrm{P}=$ percent contribution, e $=$ error, $\mathrm{F}_{\text {ratio }}=(\mathrm{V} / \mathrm{error})$, Tabulated $F$-ratio at $95 \%$ confidence level, ${ }^{*}$ Significant at $95 \%$ confidence level.

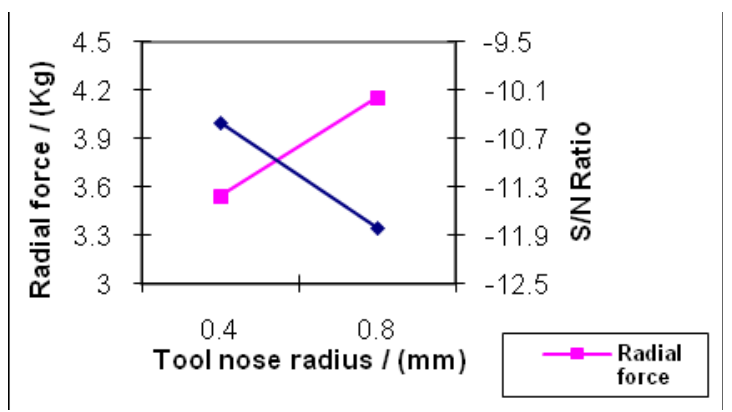

(a)

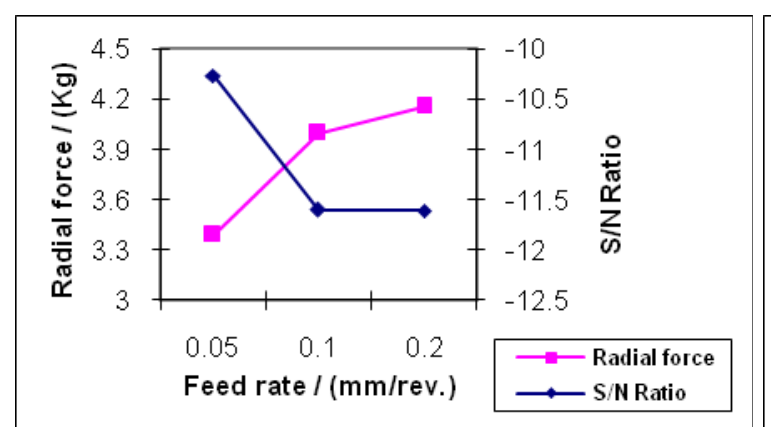

(c)

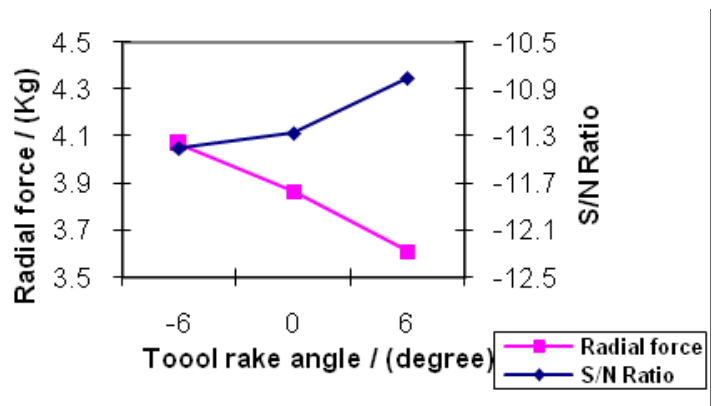

(b)

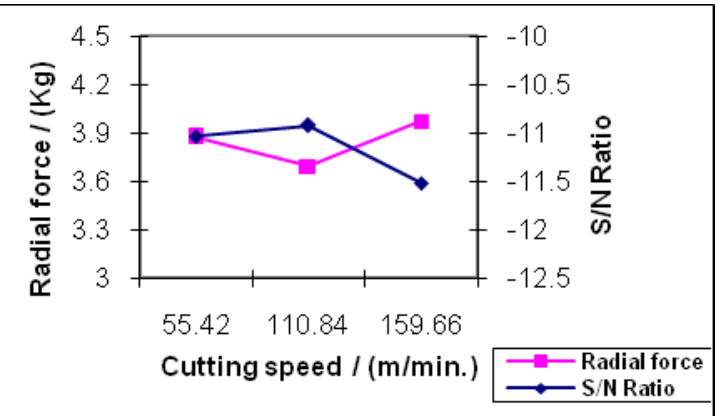

(d)

Figure: 4 Response and S/N ratio (a) effect of nose radius, (b) effect of tool rake angle, (c) effect of feed rate, (d) effect of cutting speed, 


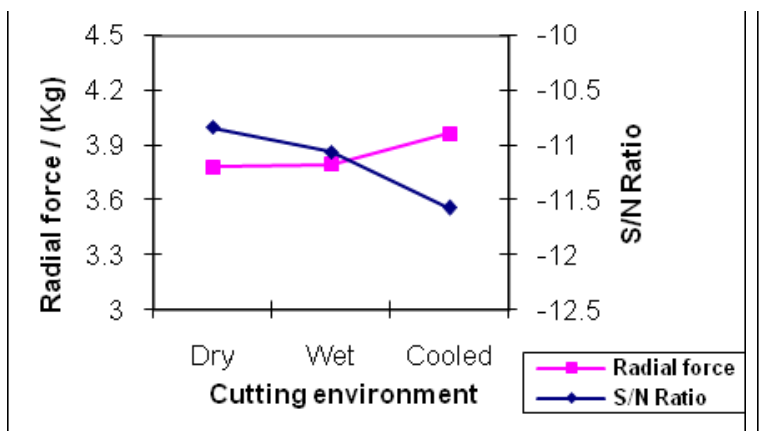

(e)

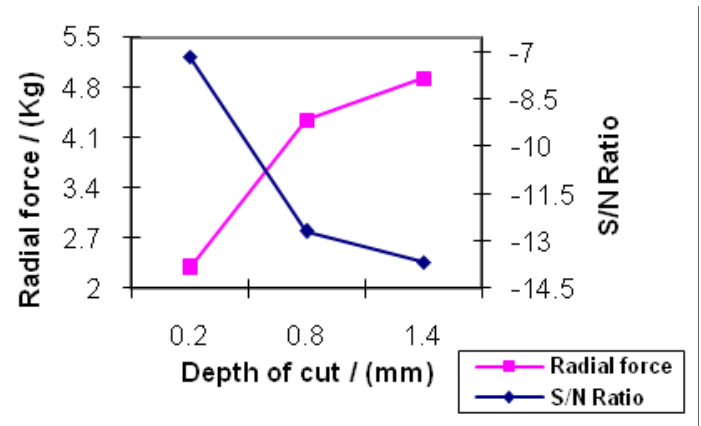

(f)

Figure: 4 Response and S/N ratio (e) effect of cutting environment, (f) effect of depth of cut.

Regression analyses are applied to identify the best levels of cutting parameters and their significance. Insignificant parameters are not taken into consideration in this Regression modeling. So that factor effects added in the error is more than $10 \%$ approximate (plus or minus).

\subsection{Regression Modeling}

A statistical software program, Minitab version 15, and Microsoft Excel are employed for model building. The goal of the multiple regression analysis was to determine the dependency of cutting forces (tangential force, feed force and radial force) to selected machining parameters. The functional relationship between dependent output parameter with the independent variables under investigation could be postulated by Equation 2 .

$$
\mathrm{Y}=\mathrm{K}\left(\mathrm{X}_{1}\right)^{\mathrm{a}}\left(\mathrm{X}_{2}\right)^{\mathrm{b}}\left(\mathrm{X}_{3}\right)^{\mathrm{c}}
$$

where $\mathrm{Y}$ is dependent output variable such as cutting force (tangential force and feed force) $\mathrm{X}_{1}, \mathrm{X}_{2}$ and $\mathrm{X}_{3}$ are independent variables such as tool nose radius, feed rate and depth of cut. The constants $\mathrm{a}, \mathrm{b}$ and $\mathrm{c}$ are the exponents of independent variables. To convert the above non linear equation into linear form, a logarithmic transformation is applied into the above equation and written as Equation 3.

$$
\log \mathrm{y}=\log \mathrm{K}+\mathrm{a} \cdot \log \left(\mathrm{X}_{1}\right)+\mathrm{b} \cdot \log \left(\mathrm{X}_{2}\right)+\mathrm{c} \cdot \log \left(\mathrm{X}_{3}\right)
$$

This is one of the most popularly used data transformation methods for empirical model building. Now the above equation is written as Equation 4.

$$
\eta=\beta_{0}+\beta_{1} \cdot x_{1}+\beta_{2} \cdot x_{2}+\beta_{3} \cdot x_{3}
$$

Where, $\eta$ is the true value of dependent cutting force (tangential force and feed force) on a logarithmic scale and $x_{1}, x_{2}$ and $x_{3}$ are respectively, the logarithmic transformation of the different parameters, while $\beta_{0}, \beta_{1}, \beta_{2}$ and $\beta_{3}$ are the corresponding parameters to be estimated. Due to the experimental error, the true response $\eta=y-\varepsilon$, where $y$ is the logarithmic transformation of the measured cutting force (tangential force and feed force) parameters and the $\varepsilon$ is the experimental error. For simplicity the equation is rewritten as

$$
\hat{\mathrm{Y}}=\mathrm{b}_{0}+\mathrm{b}_{1} \mathrm{x}_{1}+\mathrm{b}_{2} \mathrm{x}_{2}+\mathrm{b}_{3} \mathrm{x}_{3}
$$

where, $\hat{Y}$ is the predicted cutting force (tangential force and feed force) value after logarithmic transformation and $b_{0}, b_{1}, b_{2}$ and $b_{3}$ estimates of the parameters $\beta_{1}, \beta_{2}$ and $\beta_{3}$ respectively. The values of $b_{0}, b_{1}, b_{2}$ and $b_{3}$ found out by linear regression analysis, which is conducted with MINITAB standard version software (MINITAB 15.0 for windows), using the experimental data. The first order model for cutting force (tangential force and feed force) reveals lack of fitness due to high prediction errors for cutting force (tangential force and feed force). As a result, second order model has been developed ignoring the non significant parameters. $\hat{Y}=b_{0}+b_{1} x_{1}+b_{2} x_{2}+b_{3} x_{3}+b_{12} x_{1} x_{2}+b_{13} x_{1} x_{3}+b_{23} x_{2} x_{3}+b_{11} x_{1}{ }^{2}+b_{22} x_{2}{ }^{2}+b_{33} x_{3}{ }^{2} \cdots$ Equation (6). The developed empirical model for tangential force $\left(\mathrm{F}_{\mathrm{t}}\right)$ and feed force $\left(\mathrm{F}_{\mathrm{f}}\right)$ are given in Equation 6

$$
\begin{aligned}
& \mathrm{F}_{\mathrm{t}}=0.831+0.243 \mathrm{x}_{1}+(-0.566) \mathrm{x}_{2}+0.734 \mathrm{x}_{3}+(-0.153) \mathrm{x}_{1} \mathrm{x}_{2}+0.433 \mathrm{x}_{1} \mathrm{x}_{3}+0.333 \mathrm{x}_{2} \mathrm{x}_{3}+(-0.386) \mathrm{x}_{2}{ }^{2}+(-0.191) \mathrm{x}_{3}{ }^{2} \\
& \mathrm{~F}_{\mathrm{f}}=1.0+0.122 \mathrm{x}_{1}+0.030 \mathrm{x}_{2}+0.508 \mathrm{x}_{3}-0.486 \mathrm{x}_{1} \mathrm{x}_{2}+0.148 \mathrm{x}_{1} \mathrm{x}_{3}+0.127 \mathrm{x}_{2} \mathrm{x}_{3}+(-0.022) \mathrm{x}_{2}{ }^{2}+(-0.148) \mathrm{x}_{3}{ }^{2}
\end{aligned}
$$

On the other hand radial force, where $\mathrm{Y}$ is dependent output variable such as (radial force) $\mathrm{X}_{1}, \mathrm{X}_{2}, \mathrm{X}_{3}$ and $\mathrm{X}_{4}$ are independent variables such as tool nose radius, tool rake angle, feed rate and depth of cut. As a result, second order model has been developed ignoring the non significant parameters. 
$\hat{Y}=b_{0}+b_{1} x_{1}+b_{2} x_{2}+b_{3} x_{3}+b_{4} x_{4}+b_{12} x_{1} x_{2}+b_{13} x_{1} x_{3}+b_{14} x_{1} x_{4}+b_{23} x_{2} x_{3}+b_{24} x_{2} x_{4}+b_{34} x_{3} x_{4}+b_{11} x_{1}{ }^{2}+b_{22} x_{2}{ }^{2}+b_{33} x_{3}^{2}+b_{44} x_{4}{ }^{2}$

The developed empirical model for Radial force $\left(\mathrm{F}_{\mathrm{r}}\right)$ are given in Equation 7

$\mathrm{F}_{\mathrm{r}}=0.351+(-0.153) \mathrm{x}_{1}+(-0.115) \mathrm{x}_{2}+(-0.829) \mathrm{x}_{3}+0.742 \mathrm{x}_{4}+(-0.073) \mathrm{x}_{1} \mathrm{x}_{2}+(-0.399) \mathrm{x}_{1} \mathrm{x}_{3}+0.353 \mathrm{x}_{1} \mathrm{x}_{4}+(-0.083) \mathrm{x}_{2} \mathrm{x}_{3}+(-$ $0.064) \mathrm{x}_{2} \mathrm{x}_{4}+0.450 \mathrm{x}_{3} \mathrm{x}_{4}+(-0.444) \mathrm{x}_{3}^{2}+(-0.265) \mathrm{x}_{4}^{2}$

$\mathrm{x}_{1}{ }^{2}$ in $\mathrm{F}_{\mathrm{t}} \& \mathrm{~F}_{\mathrm{f}}$ and $\mathrm{x}_{1}{ }^{2}, \mathrm{x}_{2}{ }^{2}$ in $\mathrm{F}_{\mathrm{r}}$ equation are highly correlated. So there has been removed from the corresponding Equation.

Predicted output values for cutting forces (Tangential force, Feed force and radial force) are calculated with the help of above equation and the given coefficients as shown in Table 8. Relative error between predicted and measured experimental values for Tangential force, Feed force and radial force is calculated and presented in Table 9. It has been seen that relative error of cutting force (Tangential force, Feed force and radial force) are well within limits. Thus, it can be stated that empirical equation build by using second-order model can be used.

Table 8 Empirical Expressions Developed by Second Order Model

\begin{tabular}{|c|c|c|c|c|c|}
\hline Predictor & $\begin{array}{c}\text { Coefficient of Tangential } \\
\text { forces }\end{array}$ & Predictor & $\begin{array}{l}\text { Coefficient of Feed } \\
\text { force }\end{array}$ & Predictor & $\begin{array}{c}\text { Coefficient of Radial } \\
\text { force }\end{array}$ \\
\hline$b_{o}$ & 0.831 & $b_{0}$ & 1.00 & $b_{o}$ & 0.351 \\
\hline $\mathrm{X}_{1}$ & 0.243 & $\mathrm{X}_{1}$ & 0.122 & $\mathrm{X}_{1}$ & -0.153 \\
\hline $\mathrm{X}_{2}$ & -0.566 & $\mathrm{X}_{2}$ & 0.030 & $\mathrm{X}_{2}$ & -0.115 \\
\hline$X_{3}$ & 0.734 & $X_{3}$ & 0.508 & $X_{3}$ & -0.829 \\
\hline $\mathrm{X}_{1} \mathrm{X}_{2}$ & -0.153 & $\mathrm{X}_{1} \mathrm{X}_{2}$ & -0.486 & $\mathrm{X}_{4}$ & 0.742 \\
\hline$X_{1} X_{3}$ & 0.433 & $\mathrm{X}_{1} \mathrm{X}_{3}$ & 0.148 & $\mathrm{X}_{1} \mathrm{X}_{2}$ & -0.073 \\
\hline$X_{2} X_{3}$ & 0.333 & $X_{2} X_{3}$ & 0.127 & $\mathrm{X}_{1} \mathrm{X}_{3}$ & -0.399 \\
\hline $\mathrm{X}_{2}^{2}$ & -0.386 & $\mathrm{X}_{2}^{2}$ & -0.022 & $\mathrm{X}_{1} \mathrm{X}_{4}$ & 0.353 \\
\hline $\mathrm{X}_{3}^{2}$ & -0.191 & $\mathrm{X}_{3}^{2}$ & -0.148 & $\mathrm{X}_{2} \mathrm{X}_{3}$ & -0.083 \\
\hline & & & & $X_{2} X_{4}$ & -0.064 \\
\hline & & & & $\begin{array}{r}\mathrm{X}_{3} \mathrm{X}_{4} \\
\mathrm{X}_{2}\end{array}$ & 0.450 \\
\hline & & & & $\begin{array}{l}\mathrm{X}_{3} \\
\mathrm{X}_{4}{ }^{2}\end{array}$ & $\begin{array}{l}-0.444 \\
-0.265\end{array}$ \\
\hline
\end{tabular}

Table 9 Comparison between Experimental and Predicted values of Tangential forces, Feed force and Radial force

\begin{tabular}{|l|c|c|c|c|c|c|c|c|c|}
\hline & \multicolumn{3}{|c|}{ Tangential forces } & \multicolumn{3}{c|}{ Feed force } & \multicolumn{3}{c|}{ Radial force } \\
\hline $\begin{array}{l}\text { Expt. } \\
\text { No. }\end{array}$ & $\begin{array}{c}\text { Prediction } \\
\text { Value }\end{array}$ & $\begin{array}{c}\text { Experimental } \\
\text { Value }\end{array}$ & $\begin{array}{c}\text { \% } \\
\text { Error }\end{array}$ & $\begin{array}{c}\text { Prediction } \\
\text { Value }\end{array}$ & $\begin{array}{c}\text { Experimental } \\
\text { Value }\end{array}$ & $\begin{array}{c}\% \\
\text { Error }\end{array}$ & $\begin{array}{c}\text { Prediction } \\
\text { Value }\end{array}$ & $\begin{array}{c}\text { Experimental } \\
\text { Value }\end{array}$ & $\begin{array}{c}\% \\
\text { Error }\end{array}$ \\
\hline 1 & 3.59 & 3.43 & 4.337 & 2.25 & 2.17 & 3.56 & 2.12 & 1.94 & 8.65 \\
2 & 6.75 & 6.97 & -3.385 & 4.71 & 5.37 & -14.01 & 4.15 & 4.44 & -7.07 \\
3 & 8.77 & 8.37 & 4.599 & 6.82 & 6.77 & 0.78 & 5.44 & 5.68 & -4.35 \\
4 & 5.30 & 4.60 & 13.158 & 3.93 & 3.67 & 6.70 & 3.37 & 3.39 & -0.59 \\
5 & 7.64 & 8.13 & -6.485 & 5.62 & 5.60 & 0.36 & 4.52 & 4.52 & 0.07 \\
6 & 3.76 & 3.66 & 2.696 & 2.88 & 2.87 & 0.46 & 2.15 & 2.13 & 0.78 \\
7 & 5.66 & 6.19 & -9.384 & 4.59 & 4.87 & -6.03 & 3.28 & 3.23 & 1.42 \\
8 & 3.98 & 4.49 & -12.869 & 2.56 & 3.0 & -17.19 & 2.3 & 2.55 & -10.87 \\
9 & 7.33 & 7.13 & 2.656 & 5.59 & 5.40 & 3.40 & 4.51 & 3.99 & 11.60 \\
10 & 6.98 & 7.80 & -11.716 & 6.56 & 6.73 & -2.64 & 4.19 & 4.59 & -9.47 \\
11 & 10.50 & 10.12 & 3.541 & 8.69 & 8.70 & -0.12 & 5.99 & 5.73 & 4.28 \\
12 & 3.89 & 3.93 & -1.114 & 3.69 & 3.83 & -3.88 & 2 & 2.03 & -1.67 \\
13 & 3.95 & 4.20 & -6.222 & 3.54 & 3.89 & -9.89 & 2.67 & 2.75 & -3.12 \\
14 & 8.63 & 8.15 & 5.590 & 7.11 & 6.80 & 4.36 & 4.84 & 4.47 & 7.71 \\
15 & 11.67 & 11.66 & 0.040 & 9.53 & 9.70 & -1.78 & 5.66 & 5.93 & -4.83 \\
16 & 8.04 & 7.57 & 5.829 & 7.85 & 7.93 & -1.06 & 4.61 & 4.43 & 3.83 \\
17 & 4.25 & 3.81 & 10.268 & 3.63 & 3.32 & 8.54 & 2.41 & 2.27 & 5.81 \\
18 & 9.08 & 9.99 & -10.010 & 7.64 & 8.20 & -7.33 & 5.05 & 5.18 & -2.51 \\
\hline
\end{tabular}




\section{Confirmation Experiments}

The experimental study is carried out to validate the earlier developed empirical expressions for tangential, feed and radial force. Feed rate is least significant for tangential and feed force and tool rake angle is least significant for radial force as observed for ANOVA Table 6 (A), 7 (A) and 8 (A). So Feed Rate and tool rake angle remained constant at $0.1 \mathrm{~mm} / \mathrm{rev}$ and $0^{\circ}$ respectively for validation and other parameter put the same level are shown in Table 3.

Table 10 Validation between experimental and predicted results (Tangential forces, Feed force and Radial force)

\begin{tabular}{|l|c|c|c|c|c|c|c|c|c|}
\hline & \multicolumn{3}{|c|}{ Tangential forces } & \multicolumn{3}{c|}{ Feed force } & \multicolumn{3}{c|}{ Radial force } \\
\hline $\begin{array}{l}\text { Expt. } \\
\text { No. }\end{array}$ & $\begin{array}{c}\text { Prediction } \\
\text { Value }\end{array}$ & $\begin{array}{c}\text { Experimental } \\
\text { Value }\end{array}$ & $\begin{array}{c}\% \\
\text { Error }\end{array}$ & $\begin{array}{c}\text { Prediction } \\
\text { Value }\end{array}$ & $\begin{array}{c}\text { Experimental } \\
\text { Value }\end{array}$ & $\begin{array}{c}\% \\
\text { Error }\end{array}$ & $\begin{array}{c}\text { Prediction } \\
\text { Value }\end{array}$ & $\begin{array}{c}\text { Experimental } \\
\text { Value }\end{array}$ & $\begin{array}{c}\% \\
\text { Error }\end{array}$ \\
\hline 1 & 3.71 & 3.52 & 5.121 & 2.18 & 2.11 & 3.21 & 2.05 & 1.89 & 7.80 \\
2 & 6.63 & 6.91 & -4.223 & 4.85 & 5.41 & -11.55 & 3.98 & 4.22 & -6.03 \\
3 & 8.48 & 8.15 & 3.892 & 6.94 & 6.84 & 1.44 & 5.11 & 5.37 & -5.09 \\
4 & 5.35 & 4.79 & 10.467 & 3.74 & 3.56 & 4.81 & 3.51 & 3.58 & -1.99 \\
5 & 7.49 & 8.00 & -6.809 & 5.72 & 5.66 & 1.05 & 4.63 & 4.66 & -0.65 \\
6 & 3.56 & 3.49 & 1.966 & 2.99 & 2.92 & 2.34 & 2.23 & 2.19 & 1.79 \\
7 & 6.37 & 6.89 & -8.163 & 4.73 & 4.96 & -4.86 & 3.28 & 3.23 & 1.42 \\
8 & 3.70 & 4.10 & -10.811 & 2.49 & 2.8 & -12.45 & 2.54 & 2.75 & -8.27 \\
9 & 7.22 & 7.00 & 3.047 & 5.33 & 5.11 & 4.13 & 4.61 & 4.16 & 9.76 \\
10 & 7.16 & 7.92 & -10.615 & 6.79 & 6.88 & -1.33 & 4.36 & 4.71 & -8.03 \\
11 & 11.44 & 11.13 & 2.710 & 8.88 & 8.95 & -0.79 & 6.16 & 5.93 & 3.73 \\
12 & 3.99 & 4.09 & -2.506 & 3.49 & 3.68 & -5.44 & 2.13 & 2.19 & -2.82 \\
13 & 3.79 & 4.00 & -5.541 & 3.66 & 3.97 & -8.47 & 2.88 & 3.00 & -4.17 \\
14 & 8.88 & 8.53 & 3.941 & 6.96 & 6.60 & 5.17 & 5.11 & 4.83 & 5.48 \\
15 & 11.97 & 12.11 & -1.170 & 9.35 & 9.58 & -2.46 & 5.78 & 6.07 & -5.02 \\
16 & 8.18 & 7.90 & 3.423 & 7.99 & 8.05 & -0.75 & 4.95 & 4.77 & 3.64 \\
17 & 4.60 & 4.16 & 9.565 & 3.44 & 3.19 & 7.27 & 2.53 & 2.36 & 6.72 \\
18 & 9.48 & 10.23 & -7.911 & 7.51 & 8.10 & -7.86 & 4.99 & 5.10 & -2.20 \\
\hline
\end{tabular}

To verify the goodness of the predicted model, the experimental values and their predictive values of the tangential force, feed force and radial force are given in the Table 10. It has been seen that the maximum and minimum error percentage for tangential force is $(10.467$ and $-10.811 \%)$, feed force $(7.27$ and $-12.45 \%)$ and radial force is $(9.76$ and $-8.27 \%)$ which is very much satisfactory. Figure 5 show the comparison between ratios data or agreement percentage values tangential, feed and radial force.

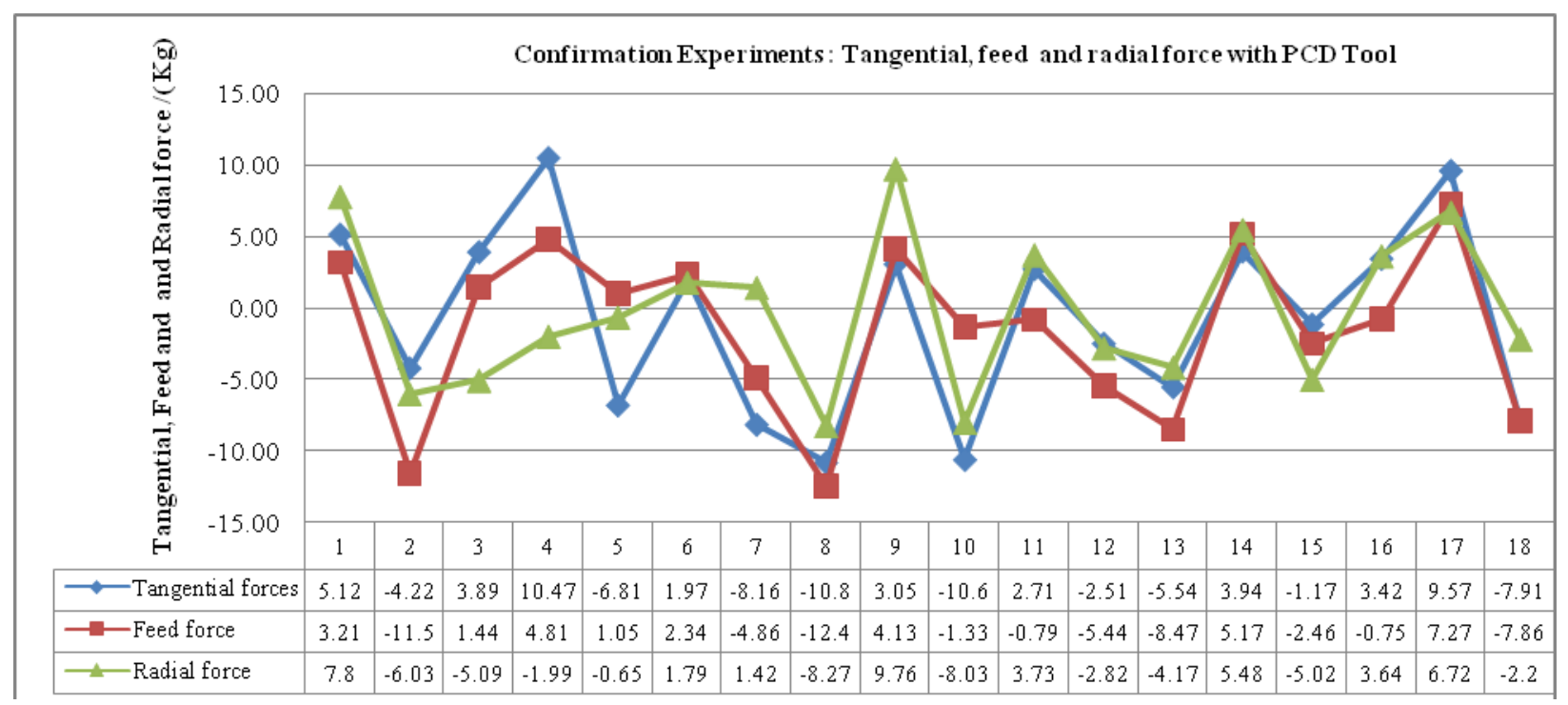

Figure: 5 Comparison between Ratios Data or Agreement Percentage Values Tangential, Feed and Radial force 


\section{Conclusions}

The important conclusions of this research work are enlisted below:

- Experiments were conducted on a lathe on unidirectional glass fiber reinforced plastics (UD-GFRP) specimens with polycrystalline diamond tool material. The data for cutting forces (tangential force, feed force and radial force) was collected under different cutting conditions.

- The percent contributions of tool nose radius $(9.65 \%)$, feed rate $(8.72 \%)$ and depth of cut $(64.07 \%)$ on tangential force are significantly larger (95\% confidence level) as compared to the contribution of the tool rake angle, cutting speed and cutting environment. Depth of cut is the factor, which has great influence on tangential force, followed by tool nose radius.

- The wet environment reduces the tangential force.

- The percent contributions of tool nose radius $(21.41 \%)$, feed rate $(4.08 \%)$ and depth of cut $(68.21 \%)$ on feed force are significantly larger (95\% confidence level) as compared to the contribution of the tool rake angle, cutting speed and cutting environment. Depth of cut is the factor, which has great influence on feed force, followed by tool nose radius.

- The cool cutting environment reduced the feed force.

- The percent contributions of tool nose radius $(5.07 \%)$, tool rake angle $(1.44 \%)$, feed rate $(5.65 \%)$ and depth of cut $(72.59 \%)$ on radial force is significantly large (95\% confidence level) as compared to the contribution of the cutting speed and cutting environment.

- The dry environment reduces the radial force.

- The second-order model for tangential force, feed force and radial force has been developed from the observed data. It was found that the maximum and minimum error percentage for tangential force is 10.467 and $-10.811 \%$, for feed force is 7.27 and $-12.45 \%$ and radial force is 9.76 and $-8.27 \%$ which is very much satisfactory.

- The developed models for cutting forces using regression modeling are highly adequate as their $\mathrm{R}^{2}$ values are very close to 1 and hence all the models can be used for reliable prediction [ $\mathrm{R}^{2}$ value for cutting forces (tangential force is $96.3 \%$, feed force is $98.2 \%$ and radial force is $97.3 \%)$ ].

- Empirical expressions have been successfully proposed to simplify the evaluation of cutting forces under different experimental conditions.

The future scope of work includes the following: (1) the number of machining parameters can be extended and hence, the data base can be improved by extensive experimentation. (2)The same problem can be modeled and analyzed by a principal component analysis and genetic algorithm.

Nomenclature
$\mathrm{b}_{0}, \mathrm{~b}_{1}, \mathrm{~b}_{2}, \mathrm{~b}_{3}, \mathrm{~b}_{4}$
$\mathrm{a}, \mathrm{b}, \mathrm{c}, \mathrm{d}$
$x_{0}, x_{1}, x_{2}, x_{3}$
$\mathrm{~F}_{\mathrm{t}}$
$\mathrm{F}_{\mathrm{f}}$
$\mathrm{F}_{\mathrm{r}}$
$\mathrm{A}$
$\mathrm{B}$
$\mathrm{C}$
$\mathrm{D}$
$\mathrm{E}$
$\mathrm{F}$
$\mathrm{K}$
$\eta$
$\mathrm{y}$
$\varepsilon$
$\hat{Y}$

\author{
Estimates of parameters; \\ Exponentially determined constant; \\ logarithmic transformations of machining parameters;

\section{Acknowledgement}

The authors are indebted to Maharashtra Engineering Industry, India (P) Limited, Satara Maharashtra for supplying the UD- GFRP rods used in this work. 


\section{References}

Abrate S. and Walton D. A., 1992. Machining of composite materials (a two part review). Composites Mfg, Vol. 3, No. 2, pp. $75 \pm 94$.

Caprino G. and Nele L., 1996. Cutting forces in orthogonal cutting of unidirectional GFRP composites, Trans. ASME, Journal Engineering Material Technology, Vol.118, pp. $419 \pm 425$.

Chen W. C., 1997. Some experimental investigations in the drilling of carbon fiber reinforced plastic composite laminates. International Journal Machine Tools Manufacturing, Vol.37, No.8, pp. 1097-1108.

Chang C. S., 2008. Prediction of cutting temperatures in turning of glass-fiber reinforced plastics with chamfered main cutting edge tools. Journal Mechanical, Vol.24, pp. 241-252.

Gordon S., Hillery M.T., 2002. A review of the cutting of composite materials. Proceeding of the Institution of Mechanical Engineers, Vol. 217, pp. 35-45.

Hussain S. A., Pandurangadu V. and Palanikumar K., 2010. Surface roughness analysis in machining of GFRP composite by carbide tool (K20). European Journal of Scientific Research, Vol.41, No.1, pp. 84-98.

Hussain S. A., Pandurangadu V. and Palanikumar K., 2011. Machinability of glass fiber reinforced plastic (GFRP) composite materials. International Journal of Engineering, Science and Technology, Vol.3, No.4, pp. 103-118.

Hussain S. A., Pandurangadu V. and Palanikumar K., 2011. Cutting power prediction model for turning of GFRP composites using response surface methodology". International Journal of Engineering, Science and Technology, Vol.3, No.6, pp. 161-171.

Isik B. and Kentli A., 2009. Multicriteria optimization of cutting parameters in turning of UD-GFRP materials considering sensitivity". International Journal Advanced Manufacturing Technology, Vol. 44, pp. 1144-1153.

Koplev A., Lystrup A. and Vorm T., 1983. The cutting process, chips and cutting forces in machining CFRP. Composites, Vol.14, No.4, pp. $371 \pm 376$.

Kim H. S. and Ehmann K. F., 1993. A cutting force model for face milling operations. International Journal Machine Tools Des Res, Vol.33, pp. 651-673.

Khan M., Adam Kumar A. and Senthil, 2011. Machinability of glass fibre reinforced plastic (GFRP) composite using aluminabased ceramic cutting tools, Journal of Manufacturing Processes, Vol.13, pp. 67-73.

Kumar S., Meenu, Satsangi P.S. and Sardana H.K., 2012. Multiple regression model for cutting force in turning UD-GFRP using polycrystalline diamond cutting tool. International Journal of Advanced Engineering Technology, Vol.3, No.1, pp. 108-112.

Kumar S., Meenu, Satsangi P.S. and Sardana H.K., 2012. Optimization of surface roughness in turning unidirectional glass fiber reinforced plastics (UD-GFRP) composites using polycrystalline diamond (PCD) cutting tool. Indian Journal of Engineering \& Materials Sciences, Vol.19, pp. 163-174.

Lee E. S., 2001. Precision machining of glass fibre reinforced plastics with respect to tool characteristics. International Journal Advanced Manufacturing Technology, Vol.17, pp. 791-798.

Mahdi M. and Zhang L. C., 2001. An adaptive three-dimensional finite element algorithm for the orthogonal cutting of composite materials. Journal Material Processing Technology, Vol.113, pp. 368-372.

Mahdi M. and Zhang L. C., 2001. A finite element model for the orthogonal cutting of fibre-reinforced composite materials. Journal Material Processing Technology, Vol.113, pp. 373-377.

Mata F., Beamud.E., Hanafi.I., Khamlichi.A., Jabbouri A. and Bezzazi M.. 2010. Multiple regression prediction model for cutting forces in turning carbon-reinforced PEEK CF30. Advances in Materials Science and Engineering, pp. 1-7.

Mkaddem A., Ibrahim C. and El Mansori M., 2008. A micro-macro combined approach using FEM for modelling of machining of FRP composites: Cutting forces analysis. Composites Science and Technology, Vol.68, No.15-16, pp. 3123-3127.

Ntziantzias I., Kechaglas J., Fountas N., Maropoulos S. and Vaxevanidis N.M., 2011. A cutting force model in turning of glass fiber reinforced polymer composite. International Conference on Economic Engineering and Manufacturing Systems Brasov, pp. 24-25.

Logothetics N., 2003. Managing for total quality. PHI, Private Limited New Delhi. pp. 422.

Paulo-Davim J., Silva L. R., Festas A. and Abrão A. M., 2009, Machinability study on precision turning of PA66 polyamide with and without glass fiber reinforcing. Materials and Design, Vol.30, pp. 228-34.

Rao G.V.G., Mahajan P. and Bhatnagar N. 2007. Micro-mechanical modeling of machining of FRP composites cutting force analysis. Composite Science Technology, Vol. 67, pp. 579-593.

Rao G., Mahajan P. and Bhatnagar N. 2007. Machining of UD-GFRP composites chip formation mechanism. Composites Science and Technology, Vol.67, No.11- 12, pp. 2271-2281.

Rajasekaran T., Palanikumar K. and Vinayagam B. K., 2011. Application of fuzzy logic for modeling surface roughness in turning CFRP composites using CBN tool. Production Enineering Res. Deve, Vol.5, pp. 191-199.

Ross P. J., 1988. Taguchi Techniques for Quality Engineering. McGraw-Hills Book Company, New York.

Roy R. K., 1990, A Primer on Taguchi Method. Van Nostrand Reinhold, New York.

Rusinek R. 2010. Cutting process of composite materials: An experimental study. International Journal of Non-Linear Mechanics, Vol.45, pp. 458-462. 
Santhanakrishnan G., Krishnamurthy R. and Malhotra S. K., 1989. High speed steel tool wear studies in machining of glass fibrereinforced plastics. Wear, Vol.132, pp. 327-336.

Sun F. H., Wu Z. Y., Zhong J. W. and Chen M., 2004. High speed milling of SiC particle reinforced aluminum-based MMC with coated carbide inserts. Key Engineering Material, Vol.274, pp. 457-462.

Sreejith P. S., Krishnamurthy R. and Malhotra S. K., 2007. Effect of specific cutting pressure and temperature during machining of carbon/phenolic ablative composite using PCBN tools. Journal of Materials Processing Technology, Vol.183, pp. 88-95.

Ubeyli M., Acir A., Keleş O. and Akçay C. E., 2011. Effect of cutting parameters on cutting force and surface roughness in milling alumina reinforced Al-6Zn-2Mg-2Cu composites. Powder Metallurgy, Vol.54, No.2, pp. 72-176.

Wang X. M. and Zhang L. C., 1999. Machining damage in unidirectional fibre-reinforced plastics, in: Abrasive Technology: Current Development and Applications I. World Scientific, Singapore, pp. 429-436.

Wang X. M. and Zhang L. C., 2003, An experimental investigation into the orthogonal cutting of unidirectional fibre-reinforced plastics. International Journal Machine Tools Manufacturing, Vol.43, pp. 1015-1022.

\section{Biographical notes}

Mr. Surinder Kumar, is a Research Scholar in the Department of Mechanical Engineering, National Institute of Technology, Kurukshetra-136119, ( Haryana), India. He was graduated in Mechanical Engineering from S.K.I.E.T, Kurukshetra, Haryana and Post graduated in the specialization of Manufacturing System from M.M Engineering College Mullana, Ambala (Haryana). At present he is pursuing (FULL-TIME) Ph.D from NIT Kurukshetra, Haryana, India. He has more than 2 years of experience in teaching. His current area of research includes Machining of composite materials, Optimization, Modeling.

Dr. (Mrs.) Meenu Gupta is an Associate Professor in the Department of Mechanical Engineering, National Institute of Technology, Kurukshetra-136119, (Haryana), India. She has more than 25 years of experience in teaching and research. Her current area of research includes Machine vision, Image processing, Optimization, Modeling.

Dr. P. S. Satsangi is an Associate Professor in the Department of Mechanical Engineering, PEC University of Technology Chandigarh, India. He has more than 25 years of experience in teaching and research. His current area of research includes Machining of composite materials, Modern manufacturing, Optimization, Modeling.

Dr. H. K. Sardana is a Scientist 'G' \& Head, in the Department of Computational Instrumentation, CSIO, Chandigarh-160030, India. His current area of research includes, Signal Processing, Computer Aided Design and Simulation, Human Physiology and Bio-Instrumentation, Digital Image Processing, Soft Computing Techniques, Computer Aided Metrology and Machine Vision.

Received March 2012

Accepted July 2012

Final acceptance in revised form August 2012 